\title{
SWEM - GREEN TECHNOLOGY FOR GENERATING FRESH WATER AND ELECTRIC POWER FROM THE ATMOSPHERIC AIR
}

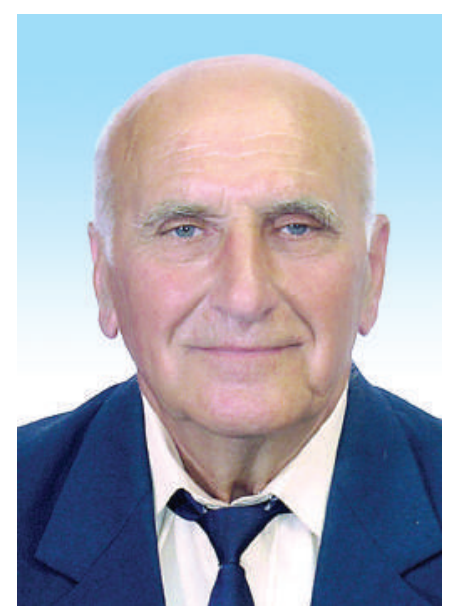

A.I. BAZHAL,

Doctor of technical Sciences, Professor

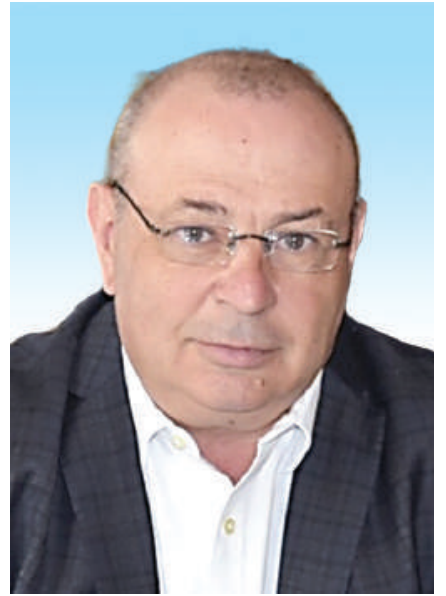

A.M. BARAK*, President, GALEX Energy Corporation

Galex Energy Corporation,

3033 Chimney Rock Road, Suite 605, Houston, TX, 77056, USA info@galexenergy.com; www.galexenergy.com

Providing fresh water and clean energy to inhabitants of remote villages of Kazakhstan, Ethiopia, Eastern China, other countries and areas where people are living in scarcity of water and energy and often are literally dying from lack of water and food is not a matter of business. It's a matter of humanity.

Making it more economic than any other sources of energy and water is the matter of business. World is spending billions of dollars trying to find water on Mars. Galex invented the most efficient and economical method providing water, power and chance of growing food on lands that was unsuitable for farming due to lack of water.

Megapolises like Almaty, Beijing, Mexico City, many others, where people suffer from respiratory diseases, having to inhale air polluted with exhausts from vehicles and power plants, states like Central Kazakhstan, California, Middle East where periodic droughts kill harvests shall no longer be subjects of those problems. Galex has a viable and economic solution to it. SWEM - efficient, cost effective and universal technology for green energy and fresh water production.

KEY WORDS: SWEM, Galex Energy, Renewable Energy, Green Energy, Fresh Water Production, Food and Water Security.

\footnotetext{
*Автор для переписки. E-mail: alex.barak5@gmail.com
} 


\title{
SWEM - ТҰШЫ СУ МЕН АТМОСФЕРА АУАСЫНАН ЭЛЕКТРОЭНЕРГИЯ АЛУҒА АРНАЛҒАН ЖАСЫЛ ТЕХНОЛОГИЯ
}

А.И. БАЖАЛ, техника ғылымдарының докторы, профессор

А.М. БАРАК, президент, Galex Energy Corporation

\author{
Galex Energy Corporation, \\ 3033 Chimney Rock Road, Suite 605, Houston, TX, 77056, USA, \\ info@galexenergy.com; www.galexenergy.com
}

Казақстан, Эфиопия, Шығыс Қытайдың шалғайда орналасқан ауыл тұрғындарын, су мен қуат тапшылығы бар басқа да елдер мен аудандарда, кейде су мен азық-түліктің жоқтығынан өліп жатқан тұрғындарды, тұшы су мен жаңғырмалы энергиямен қамтамасыз ету, бизнес мәселесі емес. Бұл адамгершілік мәселесі. Қуат пен суды қамтамасыз етудің басқа көздеріне қарағанда, осы мәселені тиімді және үнемдірек жасау, бизнес мәселесі болып табылады. Марста су табуға тырысып, Әлем миллиард долларларды жұмсайды. Жердегі мұқтаж адамдарды су және қуатпен қамтамасыз етудің тәсілін табу да, елеулі міндет. Галекс, су, электр қуатын қамтамасыз ететің және су тапшылығынан ауыл шаруашылығын жүргізуге жарамсыз болған жерлерде азық өсіруге болатын мүмкіндіктің анағұрлым тиімді және үнемді тәсілін ойлап тапты. Алматы, Бейжің, Мехико секілді басқа да көптеген мегаполистерде, адамдар автокөліктердің және жылу электр станциясы пайдаланылған газдарынан ластанған ауамен дем алуға мәжбүр болғандықтан, ауамен жұғатын аурулардан зардап шегіп отыр; Орталық Қазақстан, Калифрорния, Таяу Шығыс секілді мемлекеттер мен аумақтарда, қуаншылық мезгілінде егін құртылатын жерлер, болашақта осындай қиыншылықтарды көрмеуі тиіс. SWEM - Галекс технологиясы, осы мәселенің шешімін ұсынады. Бұл - қуат пен тұшы су өндірісінің тиімді, үнемді және әмбебап технологиясы.

HЕГІзГІ СөзДЕP: SWEM, Galex Energy, жаңартылатын энергия көздері, Жасыл энергия, тұшы су өндірісі, азық-түлік қауіпсіздігі

\section{SWЕМ - ЗЕЛЕНАЯ ТЕХНОЛОГИЯ ПОЛУЧЕНИЯ ПРЕСНОЙ ВОДЫ И ЭЛЕКТРОЭНЕРГИИ ИЗ АТМОСФЕРНОГО ВОЗДУХА}

А.И. БАЖАЛ, доктор технических наук, профессор, главный научный сотрудник А.М. БАРАК, Президент GALEX Energy Corporation

Galex Energy Corporation, 3033 Chimney Rock Road, Suite 605, Houston, TX, 77056, USA info@galexenergy.com; www.galexenergy.com

Обеспечение пресной водой и возобновляемой энергией жителей отдаленных деревень Казахстана, Эфииопии, Восточного Китая, многих стран и районов, где люди живут в условиях дефицита воды и энергии и порой буквально умирают от отсутствия воды и продовольствия это не вопрос бизнеса. Это вопрос гуманности.

Сделать это более эфрфективным и экономичным, чем любые друаие источники обеспечения энергией и водой, является вопросом бизнеса. Мир тратит миллиарды долларов, пытаясь найти воду на Марсе. Найти способ обеспечить нуждающихся в воде и энергии на Земле - задача не менее насущная. Галекс изобрела наиболее эффрективный и экономичный метод, обеспечивающий водой, электроэнергией и возможностью выращивания продовольствия на землях, которые до этого были непригодны для ведения сельского хозяйства из-за нехватки воды.

Мегаполисы, такие как Алматы, Пекин, Мехико, многие другие, где люди страдают 
от респираторных заболеваний от того, что вынуждены дышать воздухом, загрязненным выхлопными газами автомобилей и теплоэлектростанций; государства и территории, такие как Центральный Казахстан, Калифорния, Ближний Восток, где периодические засухи уничтожают урожаи, больше не должны испытывать эти проблемы. SWEM - mехнология Галекс предлагает решение этой проблемы. Это эффрективная, экономичная и универсальная технология производства возобновляемой энергии и пресной воды.

КЛЮЧЕВЫЕ СЛОВА: SWEM, Galex Energy, возобновляемые источники энергии, зеленая энергия, производство пресной воды, продовольственная безопасность.

W ater scarcity is a global crisis. It's a known fact. The water and food growing scarcity for many years was recognized as the greatest problem of the Earth. Only recently the Global Warming has become the more outspoken concern at the highest level of world forums of all kinds. For many people's opinion the cause of the global warming is the carbon dioxide emission caused by burning fossil fuel in order to get the energy for our being. We must say upfront we do not support that point of view as we believe the global warming is caused byunproportionally more significantnatural factors, unrelated to human activities. However, we agree that carbon emission is bad as it pollutes the air we are inhaling and living in. Should the competitive renewable sources of energy become available it would make sense to use it instead of the coal, oil and gas. The competition, however, must be fair.

SWEM is the renewable energy and fresh water technology of Galex that resolves both of those problems at once. Moreover, they cost less than any other sources of energy and fresh water.

Water covers $70 \%$ of the surface of the Earth. So why are we talking about water crisis? The answer is as simple as it is scary and tragic. In average there is more than enough fresh water on Earth but unfortunately the distribution of water is uneven and unfair. Russia, Canada, Brazil, Northern Europe enjoy huge surplus of fresh water resources. Besides, those countries have most of rain water. Other areas at the same time suffer from deadly draughts and hungers. There is not enough, and often lack of, fresh water in the areas most inhabited by people. As of these days a half of a billion people live under severe water and food scarcity year-round. Those are people living predominantly in Middle East and Africa. The area defined by a triangle of South of Spain - Pakistan - Horn of Africa. Four billion people, that accounts for three quarters of the world population, live under severe water scarcity at least one month a year.

By 2050 Earth populations is prognosed to increase by $55 \%$. Shall we survive the global warming the food and fresh water supply problems will grow into deadly ones, unless resolved.

The situation is aggravated with the human factors of using the water. One of the most significant of those factors is overuse of the water. Such overuse of the water may be split into three groups of factors. They are:

Agricultural overuse. Definitely the champion of the use and overuse of fresh water. About $70 \%$ of the fresh water use account to the agriculture. The share of irrigated agricultural land grows fast and is a subject of special attention to scientists and engineers. 


\section{ИННОВАЦИОННЫЕ ТЕХНОЛОГИИ GALЕХ}

Areal irrigation is total waste of the water, especially in the hot climate environment. Up to $94 \%$ of the water spread on a dry cultured land evaporates into atmosphere from the hot surface and not participating at all in watering the roots of the plants it was used for. The water dripping technology improved the ratio by large margin and made possible to grow produce on land that had been thought not usable for agriculture for thousands of years. Israel is now one of the largest suppliers of vegetables, fruits and barriers to many European and Asian markets. Still, this dripping technology allows a large portion of the water to be evaporated from the surface before it reaches the roots. At Galex we have developed technology of under-surface moist transmission, as well as technology of absorbing water from the atmospheric air. In one of the later publications this technology will be presented.

Industrial overuse. The better term for this is abuse. Mostly this relates to severe contamination of fresh water followed with dumping it into reservoirs where such contaminated water mixes in and contaminates the entire reservoir. In many countries the control over prevention of contamination is loose due to corruption, low standards and poor maintenance of the equipment.

Social habits of overuse of water. Surprisingly, that particular issue is more relevant to the countries and areas where water has traditionally been regarded as treasure. For example, the per capita use of the water in Saudi Arabia, UAE, other countries of the Gulf are over 500 liters per day, while internationally recognized standard is 130 to 150 liters per day. Singapore, that lacks natural water sources and only uses desalinated sea water, purifiedsecond hand water and whatever water imported from Malaysia, uses 290 liters per capita.

Another human factor that sometime leads to catastrophic outcomes is ignorance of the voice of scientists by political rulers. Crimea is the latest example of such ignorance. From the Soviet days it's been known that the ground water at the peninsula is a matter of special care and limited use. The formation pressure at the water bearing zone must had been maintained and the extraction of it strictly controlled. That requirement was neglected lately. Water from the water wells was overdrawn and the pressure in the water zone dropped below critical level. As the result, the sea water seeped into the zone saturating theground water reservoir that before was saturated with fresh water.The soil becomes salted. This is an irreversible process that progresses on taking more territory. The vegetation on that land is doomed to die. The land will turn into saline desert similar to Kalmykia or salt-marsh land of Western Kazakhstan near the Caspian Sea. The Crimea case is a developing example of a technogenic problem caused by humans. There are more examples of this phenomenawhere ignorance of science and negligence of care by the governing authorities created natural disasters.

Half of the world largest cities express fresh water scarcity. Singapore, Cape Town, Jakarta, Cairo, Beijing, Istanbul, Tokyo, Miami, London, etc. are just a few names in a long line of world metropolises that suffer from water scarcity. Those are also the largest users of electric power for life support, accumulators of motor vehicles, industrial hubs. The most of the power is generated from coal, oil and natural gas producing great deal of carbon dioxide, poisonous gases that pollute the air we breathing. In the \#3 issue of 2019 we published an article about SALF technology that provides for $30 \%$ or more of fuel 
efficiency in internal combustion engines. Using SALF devices in cars, trucks and marine vessels could help in reduction of fossil fuel consumption and, therefore, carbon emission reduction. It's understandable that it will take time for the EVs to fully replace the ICE vehicles on the road but in the meantime SALF could be a solution reducing the emission.

As far as the electric power stations, factories and plants are concerned, SWEM could be a solution providing ample amount of electric power for very competitive prices, while ensuring the air in the cities stays clean. The main electric power station in Almaty, the TEC-2, is by far the biggest air polluter of the metropolis where the air is notoriously toxic. The power station generates electricity by burning coal. Population in Beijing is choked with air pollution. Cairo, Mexico-City and most other world metropolises would jointhe "Me Too!"movementbegging for cleaner air in their respective cities.

SWEM generates pure fresh water and electric power directly from the atmospheric air. It is $100 \%$ green. The capital construction cost is a fraction of any competitive methods of power and water production. The operating cost negligently low.

SWEM is uniform, can fit to rural environment as well as urban busy infrastructure. SWEM addresses the future demand for power and water, including for agricultural use.

Galex spent nearly twenty years developing this technology and is proud to present this

\section{UNIQUE ULTRA-LOW-COST METHOD GENERATING FRESH WATER AND POWER FROM ATMOSPHERE}

The basis for SWEM is our patented principals of concentration and utilization of low-potent thermal energy dissipated in the atmosphere.

For the SWEPTtechnology in particular a hurricane-like model of power concentration, accumulation, conversion and release was utilized.

Natural hurricanes is also a great illustration of the magnitude of energy and water that can be generated from the atmosphere without any outside source of power. Hurricanes are naturally triggered, developed, grow into incomparable water mass and power that are released back into nature without any benefits to us. Instead,hurricanes are accountable for many lives, billions of dollars in damages.

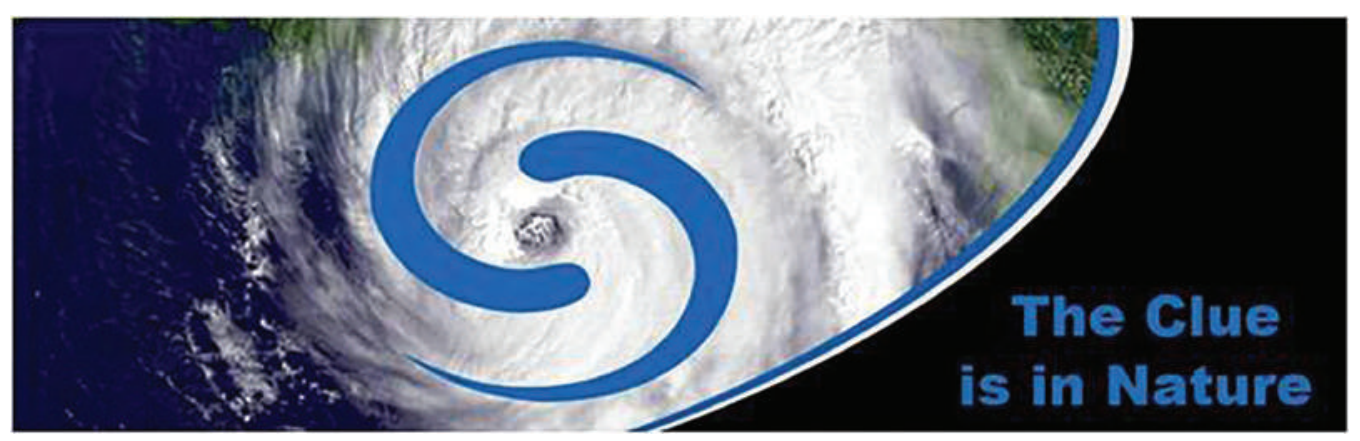

Pic. 1 - Space photo of an actual hurricane Alex of June 2010. The image is chosen as a logo of Galex Energy Corp. In 2010 the fundamental principles of the technology were defined. Following R\&D efforts were to determine numerical values of certain critical elements, refine and model a modular. 


\section{ИННОВАЦИОННЫЕ ТЕХНО^ОГИИ GALЕХ}

TheGalex's team of scientists analyzed and assessed the enthalpy of inter-phase energy transitions and processes that occur in real hurricanes, made numerous of lab tests to empirically prove or correct the assumptions given to certain constants. As the result, a model replicating a micro-hurricane put in a frame was developed.

Here is how SWEM works:

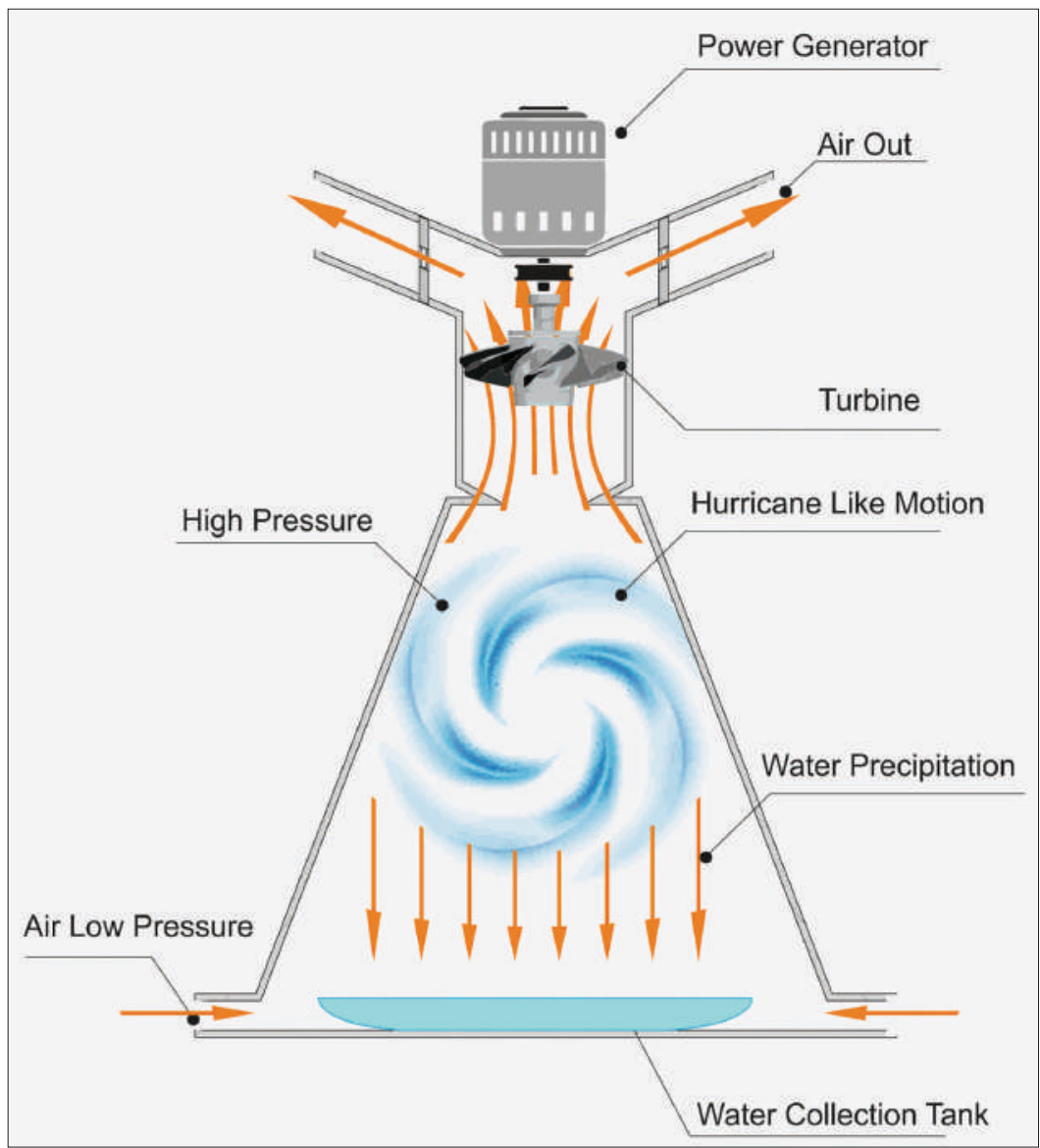

Pic. 2 - Sketch-diagram of a SWEM unit illustrating the process for presentation. The low-potent thermal energy transmission process:

Sun sends its rays on Earth warming up the surface, which is $70 \%$ water. The sun energy is realized in the vapor - the moistvaporized from the sea surface.

Based on a natural pressure gradient the air is sucked into the apparatus, given it vortex motion and split into low- and high-pressure zones - exactly the way it occurs in natural hurricanes. The low- and high-pressure zones in the apparatus are distributed in a controlled fashion.

The air is spinning up at accelerated velocity. The low-pressure zones within the apparatus provide conditions for the moist to precipitate from the air and be collected in a collection tank. The precipitation energy is released. 
The energy further realized in acceleration of the now dry air giving it an axial vector. The air is losing density but is increasing the lineal velocity.

The energy-empowered moist-free air moves up the modular at accelerated velocity. A turbine followed with a power generator placed at the top exit point of the SWEM apparatus converts the air flow into electric power.

Gradually the intensity of the operation grows to the designed optimum level. As the regime reaches its optimal level, an efficiency factor of removal of 50 to $70 \%$ water from the air is achieved.

At $100 \%$ saturation $1 \mathrm{~m}^{3}$ of air contains from 22 to 25 grams of water depending on the temperature. The higher the temperature of the air the greater amount of water it saturates.

Summarizing the description, the low potent sun energy dissipated in the air is concentrated and realized in fresh water collected in the collection tank and electric energy produced by turbo-generator.

Production of water and power varies depending on air temperature, actual water content, selected and adjusted design factors. That, in turn, varies upon seasons, day/night sequence, actual weather conditions.

Scalability: During FEED phase of a project a small test modular of SWEM apparatus will have to be built to provide input data for design and scale of the industrial unit or a battery of units. The design criteria for the SWEPT water/energy plant should determine the water and power minimum output. The weather fluctuation factors must be assessed and accounted for. The designed production should be calculated with additional factor providing 20-25\% excess vs to the possible maximum production output.

Criteria: During the FEED phase the main design criteria should be defined. For instance: $1 \mathrm{gWt}$ of electric power. The design will be performed targeting that main criteria, so the water output will be calculated accordingly and derived from as the result of the size and shape of the energy plant. And vice versa, should water production become the main design criteria the energy will be the calculated outcome resulting from the size and shape of the water plant.

Cost: In the industry generating power the capital construction cost various electric power generating plants spreads in a range of $\$ 1 \mathrm{MM}$ to $\$ 5 \mathrm{MM}$ per $\mathrm{kWt}$. Galex will guaranty capital cost of SWEM way under $\$ 0.5 \mathrm{MM}$ per $\mathrm{kW}$. Water comes free.

Same logic followed fresh water production. In the industry desalinating water, an average CapEx of desalination plan is assessed at \$1MM for 1,000 mt per day capacity. Galex will guaranty SWEM CapEx way under $50 \%$ of the lowest comparable water desalination technology. Power comes free.

Shape, size and applicability: The following slides provide examples of possible sizes, shapes and designs of SWEM unit providing applicability of the technology to any need from giga-size power/water plants providing life support to Singapore, Abu-Dhabi or Riyad to a mobile water/power unit for a small animal farm, a street corner station for charging EVs, an elevator chute shape unit providing power and water to a ski-scrapper, many other application specifics.

Sizes, Shapes and Applicability: 


\section{ИННОВАЦИОННЫЕ ТЕХНО^ОГИИ GALЕХ}

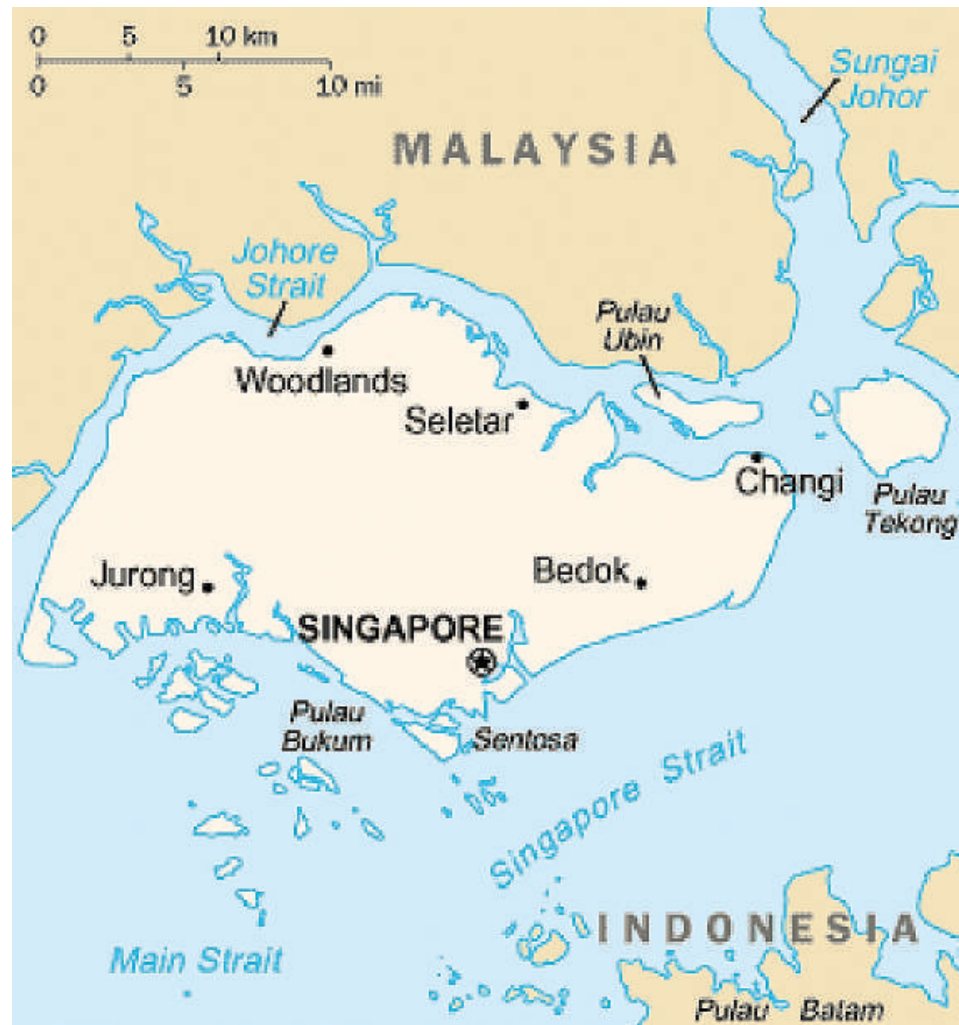

Pic. 3 - Singapore surrounded with water. A picture perfect for a spread-out concept providing water and power for life support. The 5.7 million people metropolis may become completely self-sufficient providing low cost fresh water and power for the current and future life support

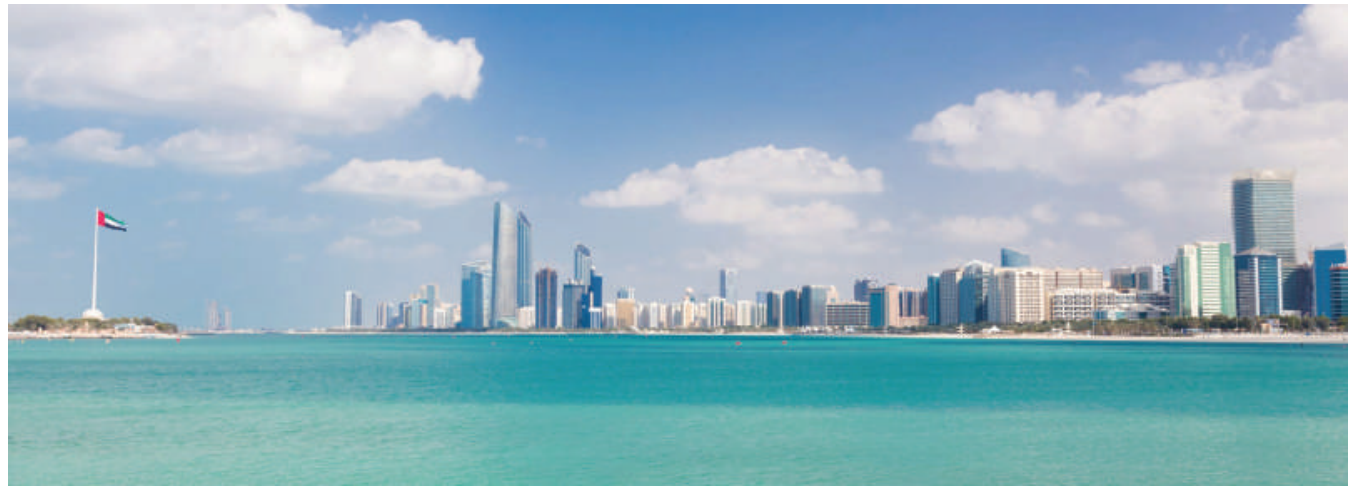

Pic. 3 - Abu-Dhabi is another costal metropolis with futuristic Masdar-City division that may find viable resolution to its water/power scarcity with SWEM technology. Never has to use purified second-hand water any more. Excess water can be used to turn the desert around the metropolis into agricultural land. 


\section{ИННОВАЦИОННЫЕ ТЕХНОЛОГИИ GALEX}

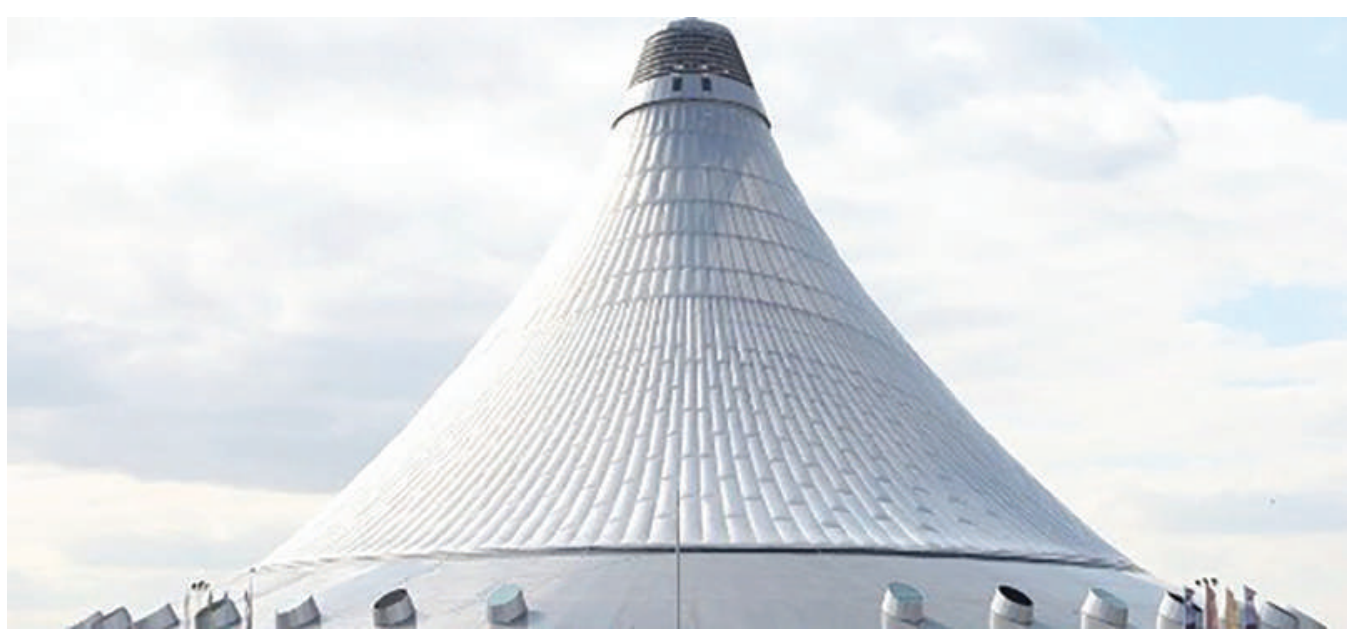

Pic. 4. - A mega power/water plant shape. Could be builtat a sea cost, offshore foundation or in a desert.

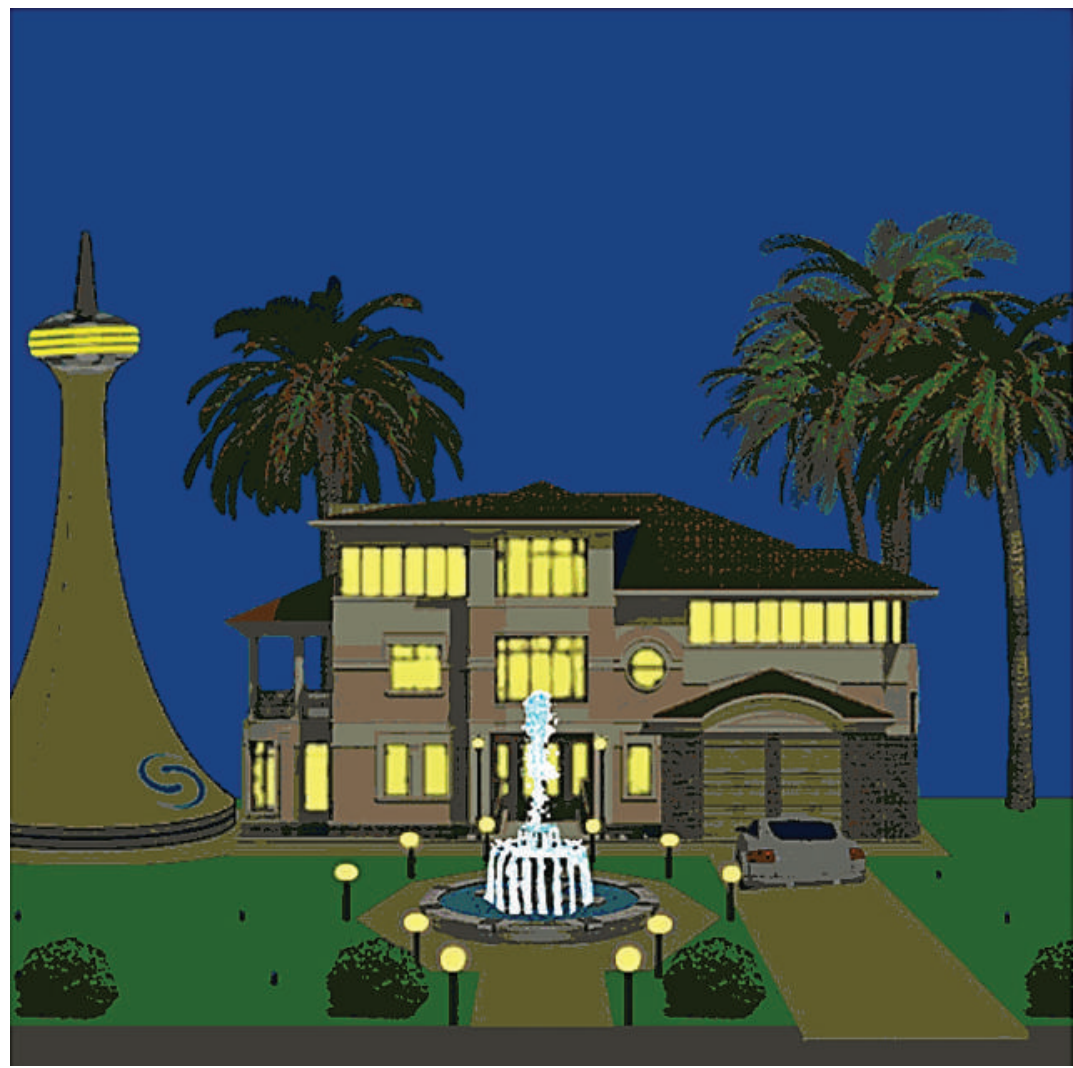

Pic. 5 - An example of a small unit to provide power to a village, mansion, mobile military squad, animal farm or temporary settlement. Provides for $100 \%$ autonomous supplies of power and water. 